\title{
PHYLOGENETIC ANALYSIS OF BLACK BENGAL AND JAMUNAPARI GOATS IN BANGLADESH BASED ON PARTIAL SEQUENCE OF CYTOCHROME B GENE
}

\author{
S.M.Z.H. Chowdhury ${ }^{1 *}$, M.S. Mahmud ${ }^{1}$, M.R. Islam ${ }^{1}$ and K.H.M.N.H. Nazir ${ }^{2}$ \\ ${ }^{1}$ Livestock Division, Bangladesh Agricultural Research Council, Farmgate, Dhaka, Bangladesh. \\ ${ }^{2}$ Department of Microbiology and Hygiene, Bangladesh Agriculture University \\ Mymensingh-2202, Bangladesh.
}

\begin{abstract}
Goats, among the livestock species, are considered the most prolific ruminant especially under callous climatic conditions. The aim of the present study was to depict the current phylogenetic status and genetic diversities of Black Bengal (BBG) and Jamunapari goat of Bangladesh and the world. Cytochrome b (cytb) gene (1140 bp) of mitochondrial DNA of Black Bengal goats (Capra hircus) was amplified by Polymerase Chain Reaction (PCR) for the first time in Bangladesh. The sequence from BBG had no nucleotide (nt) difference and $100 \%$ homology with the BBG (C. hircus) of India and also the goats (C. hircus) from China (Yangtze River Delta White Goat), Thailand (Wild Cervidae), Japan (Bezoar goat) and South Africa (Domestic goat). The sequence had 1-5 nt differences and $99 \%$ homology with the goats (C. hircus) from China, Thailand and Japan (other goats), and also with the goats (C. hircus) from Malaysia, South Korea, France, Italy, Pakistan, Slovenia, Switzerland and USA. Phylogenetic tree constructed with Black Bengal Goat (BBG-K-2) and Jamunapari goats (SG-1) of Bangladesh with cytochrome b nucleotide sequences were closely related to China-HM7. China-YP xj46, Pakistan-Lineage C1, Pakistan-Lineage C2, SloveniaChSo1, Switzerland-ChTo2992 and shared $98.8 \%$ to $99 \%$ and $98.3 \%$ to $98.6 \%$ similarity, respectively and $1-1.2 \%$ and 1.4 to $1.7 \%$ genetic distance, respectively. Based on $\mathrm{Ctb}$ gene Sequence collected from Bangladeshi Black Bengal Goats (BBG-K-2) and Jamunapari goats (SG1) that were closely related and shared with the same genetic lineage of China HM18 and India-BBG-DQ073048, respectively, suggesting a common origin.
\end{abstract}

Keywords: Domestic Goats, Genetic Diversity, mtDNA, cytb Gene, Phylogenetic Analysis

\footnotetext{
*Corresponding author: ziqru106@yahoo.com
} 
Chowdhury et al.

\section{INTRODUCTION}

Archaeological evidences indicated that goats were the first ruminant animal to be domesticated 10,500 years ago around the Fertile Crescent (Fernández et al., 2006; Zeder, 2008). There were two suggested wild species of the genus Capra (C. aegagrus and $C$. falconari), with the closest candidate $C$. aegagrus, which domestic goat gene pool was derived from (Mannen et al., 2001). Analyses of the control region (the displacement-loop) of mitochondrial DNA (mtDNA) and nuclear DNA are most useful examinations and are informative genomic elements for explicating the origin, diversity, genetic relationship and diversification of livestock including goat (Dorji et al., 2010).

In Bangladesh, the rearing of goats is a profitable household enterprise for rural populations due to the animal's prolific breeding potential, survivability and consumption of locally collected feed (Islam et al., 2011). Economy of Bangladesh is mainly driven by agricultural product and livestock is the most viable sector. Livestock is contributing about $2.73 \%$ of overall Gross Domestic Products (GDP) and $4.31 \%$ export earnings from leather and leather goods of total export, $20 \%$ of the population is directly and $50 \%$ is partly dependent on this sector (Draft Sixth Five Year Plan, 2010). Goat (66.6 million) and Sheep (29.1 million) in Bangladesh have valuable contributions to the economy of the country (DLS, 2018).

Recently, molecular studies of goats based on mitochondrial DNA (mtDNA) sequences have been carried out to investigate the origin and phylogeny of goats (Mannen et al., 2001). Mitochondrial DNA is very useful for its multiple presences in cells. The most of animal mtDNA is coding 37 genes (Avise, 1994). One of them, Cytochrome $b(C y t b)$ is one of the genes encoded by mitochondrial deoxyribonucleic acid (mtDNA). The mtDNA sequence has been used extensively in the study of genetic evolution because it is easy to obtain, has a high value in evolution, and generally follows a pattern of inheritance compatible with phylogenetic reconstruction (Jain et al., 2007). The uniqueness of $C y t b$ is one of the proteincoding genes involved in the transport of electrons in the respiratory chain; it can be determined as a target for evolutionary analysis and species identification, particularly useful for comparing species within the same genus or the same family and also can be used to study genetic diversity through mtDNA sequences (Manceau et al., 1999; Castresana, 2001; Mohammadi et al., 2018). Amino acid sequence on $C y t b$ gene can be used to clarify Kejobong goat phylogenetic status among several Asian local goats (Lestari et al., 2018).

Characterize and molecular sequencing of Cytochrome b gene of Mitochondrial DNA in Bangladeshi goat genome was evident in our previous endeavor (Chowdhury et al., 2011). The present study was investigated to current phylogenetic status and genetic diversities of Black Bengal and Jamnapari goat of Bangladesh and the world in order to understand the genetic basis of this breed. 


\section{MATREIALS AND METHODS}

\section{Breed selection}

There were two different local breeds Black Bengal and Jamnapari goats of Bangladesh selected for this research study.

\section{Study area}

This study was conducted in three different goat farms located in semi-urban area of Savar region of Dhaka and Khulna for Black Bengal goats, Gazipur area for Jamnapari goats in Bangladesh during the period 2010 to 2011. Three goat farms are designated as farm code A, B, and C. The samples were collected from the three goats of selected farms and brought to the Department of Microbiology and Hygiene, Bangladesh Agricultural University, for laboratory analysis.

\section{Sample collection}

A total of 3 blood samples from individual goats of 2.5 years of age were collected from jugular vein each from three selected goat farms. Blood samples of Black Bengal goat were taken from Khulna (BBG-K-2), Dhaka and Jamunapari goats from Sardagonj of Gazipur (SG-1) area of Bangladesh. All blood samples (5ml in EDTA Containing tubes) were aseptically collected and stored at $-20^{\circ} \mathrm{C}$ until used at Microbiology laboratory. The goat samples were unrelated genetically based on the information of the owners and local breeding data. Processing of blood samples was followed by Chowdhury et al. (2011).

\section{DNA extraction, amplification, and sequencing of $\boldsymbol{c y t} \boldsymbol{b}$ gene}

DNA was extracted from whole blood using the method as described by Chowdhury et al (2011) for sequence analysis $C y t b$ gene in mtDNA. All DNA samples were brought to the final concentration of $50 \mathrm{ng} / \mu \mathrm{L}$ and stored at $-80^{\circ} \mathrm{C}$. The forward primer (5'-ATG ACC AAC ATC CGA AAG ACC C-3' (nt 1-22)) and reverse primer (5'-TCT TCA TTT TAG AAG GTT GTT TCC-3' (nt 1140-1117) that generated 1140 bp polymerase chain reaction (PCR) product were used to amplify 1140 bp of Cytb gene as described by Takada et al (1997) and Chowdhury et al (2011).

\section{Sequence Alignment and identification}

Partial sequences, obtained using forward and reverse primers of mtDNA $C y t b$ sequences were combined to full length sequences (420 bp for Black Bengal) via the SeqMan Genome Assembler (DNAstar, USA) and were compared to the Gene Bank database of the National Center for Biotechnology Information (NCBI) (http://www.ncbi.nlm.nih.gov/GenBank) by means of the basic local alignment search tool (BLAST) to identify close phylogenetic relatives. The nucleotide sequences then were translated into amino acids form by mitochondrial vertebrate genetic code. All mtDNA $C y t b$ sequences were analyzed using Molecular Evolutionary Genetics Analysis 6 program (Tamura et al., 2013) and aligned by ClustalW (Thompson et al., 1994). 
Partial cyt $b$ gene sequence (N-terminal part) of mtDNA of Jamnapari goat from Gazipur was published (Chowdhury et al., 2011). Based on the resulted partial cyt $b$ gene sequence (N-terminal part) of mitochondrial DNA of Black Bengal goat (Bangladesh-BBG-K-2) of Khulna district, similar sized sequence was taken from that of Jamnapari goat (Bangladesh-Jamnapari-SG) and that of 42 other goats of different countries from Gene Bank Databases. Multiple alignment was carried out using Lasergene MgAlign program of DNASTAR Software (http://www.dnastar.com, Product Key: NXRAY-GQ8NJ-EKJW7). Sequence distances were obtained using MgAlign Distance ClustalW.

\section{Construction of Phylogenetic tree}

The multiple sequence alignment of the retrieved reference sequences from NCBI, EMBL or DDBJ and representative isolates' sequences were performed with the ClustalW (Larkin, Blackshields et al., 2007) software. Aligned sequences were exported to the GeneDoc software for sequence trimming and conserved region identification. Refined sequences were further exported to the Molecular Evolutionary Genetic Analysis (MEGA) (Tamura and Dudley, 2007) software for phylogenetic tree construction using the Neighbor joining algorithm and selecting 1000 bootstrap replication. Further analysis of the genes was carried out using the Distance and Pattern analysis tool in the MEGA software. The phylogenetic tree was inferred using the Neighbor-Joining method (Saitou and Nei, 1987). A bootstrap consensus tree was inferred from 1000 replicates (Felsenstein, 1985).

\section{Nucleotide sequence accession numbers}

The partial mtDNA Cytochrome B gene sequences obtained in this study have been deposited in the GenBank database under the accession numbers MN066604 for Black Bengal goat (BBG-K-2) and MN066605 for Jamunapari goat (SG-1). The mtDNA Cytb gene sequences were displayed within the phylogenetic tree and the accession numbers are listed in Table 1. Isolates name have been abbreviated using the following format: country/organization/location/isolate no.

Table 1. List of $C y t b$ gene sequences of goats used in phylogenetic analysis

\begin{tabular}{cllll}
\hline Serial no. & Goat Species & Country & Accession No. \\
\hline 1. & Capra hircus (Isolate: BBG-K-2) & Bangladesh & MN066604 \\
2. & Capra hircus (Isolate: SG-1) & Bangladesh & MN066605 \\
3. & Capra hircus (Isolate:D-LK18) & China & GU229281 \\
4. & $\begin{array}{l}\text { Capra hircus (Isolate: G32, breed: } \\
\text { Yangtze River Delta White Goat) }\end{array}$ & China & EU130773 \\
5. & Capra hircus (Isolate: G45, breed: & China & EU130774 \\
& Yangtze River Delta White Goat) & & \\
6. & Capra hircus (Isolate: HM7, breed: & China & EU130780 \\
\hline
\end{tabular}




\begin{tabular}{|c|c|c|c|}
\hline Serial no. & Goat Species & Country & Accession No. \\
\hline & Yangtze River Delta White Goat) & & \\
\hline 7. & $\begin{array}{l}\text { Capra hircus (Isolate: HM13, breed: } \\
\text { Yangtze River Delta White Goat) }\end{array}$ & China & EU130775 \\
\hline 8. & $\begin{array}{l}\text { C. hircus (Isolate: HM18, breed: } \\
\text { Yangtze River Delta White Goat) }\end{array}$ & China & EU130776 \\
\hline 9. & $\begin{array}{l}\text { C. hircus (Specimen_voucher:YP } \\
\text { xj46) }\end{array}$ & China & DQ089480 \\
\hline 10. & C. cylindricornis (East caucasian tur) & France & AF034737 \\
\hline 11. & C. caucasica (West caucasian tur) & France & AF034738 \\
\hline 12. & C. ibex (Ibex) & France & AF034735 \\
\hline 13. & C. falconeri (Markhor) & France & AF034736 \\
\hline 14. & C. nubiana (Nubian ibex) & France & AF034740 \\
\hline 15. & Capra hircus (Isolate: V07-146) & France & GU295658 \\
\hline 16. & C. aegagrus (wild goat) & France & AF034739 \\
\hline 17. & Capra hircus (breed: black Bengal) & India & DQ073048 \\
\hline 18. & C. hircus & India & EF056502 \\
\hline 19. & $\begin{array}{l}\text { C. aegagrus cretica (subspecies- } \\
\text { cretica) }\end{array}$ & Israel & AF217255 \\
\hline 20. & Capra hircus (Strain- breed Baladi) & Israel & AF217254 \\
\hline 21. & C. hircus & Italy & AF533441 \\
\hline 22. & C. hircus & Japan & AB004073 \\
\hline 23. & C. hircus & Japan & AB004074 \\
\hline 24. & C. hircus & Japan & D84201 \\
\hline 25. & $\begin{array}{l}\text { C. hircus (Strain: Laos native, Isolate: } \\
\text { Laos-1) }\end{array}$ & Japan & AB044307 \\
\hline 26. & $\begin{array}{l}\text { C. hircus (Strain : Laos native, Isolate: } \\
\text { Laos-5) }\end{array}$ & Japan & AB044308 \\
\hline 27. & C. falconeri ( Markhor) & Japan & AB044309 \\
\hline 28. & C. hircus (haplotype: ChMy50) & Malaysia & DQ514545 \\
\hline 29. & C. hircus (Strain: Lineage C1) & Pakistan & AB110594 \\
\hline 30. & C. hircus (Strain: Lineage C2) & Pakistan & AB110595 \\
\hline 31. & C. hircus (Strain: Lineage D1) & Pakistan & AB110596 \\
\hline 32. & C. hircus (Strain: Lineage D2) & Pakistan & AB110597 \\
\hline 33. & C. aegagrus blythi (Strain: Sindh Ibex 1) & Pakistan & AB110592 \\
\hline 34. & C. aegagrus blythi (Strain: Sindh Ibex 2) & Pakistan & AB110593 \\
\hline
\end{tabular}




\begin{tabular}{r|l|l|l}
\hline Serial no. & Goat Species & Country & Accession No. \\
\hline 35. & C. hircus (haplotype ChGr642) & South Africa & DQ514544 \\
36. & Capra hircus (Isolate: a-105) & South Korea & EU259119 \\
37. & Capra hircus (Isolate: b-109) & South Korea & EU259120 \\
38. & Capra hircus (Isolate: e-139) & South Korea & EU259132 \\
39. & C. hircus (haplotype: ChSo1) & Slovenia & DQ514547 \\
40. & C. hircus (haplotype: ChTo2992) & Switzerland & DQ514548 \\
41. & Capra hircus (Isolate:Goat01) & Thailand & FJ556564 \\
42. & Capra hircus (Isolate:Goat03) & Thailand & FJ556557 \\
43. & C. hircus & USA & X56289 \\
44. & C. aegagrus (wild goat) & Japan & AB004069 \\
\hline
\end{tabular}

\section{RESULTS AND DISCUSSION}

We analyzed cytochrome b sequences to identify Bangladeshi goat phylogeny as well as to discern the genetic diversity of goat breeds/populations. Two different goat breeds, Black Bengal (MN066604) and Jamunapari (MN066605) goats, were detected in Bangladesh. Two sequencing reactions (forward and reverse) for each sample gave 606 bp sequence for a Jamunapari goat (Chowdhury et al., 2011) and 420 bp sequence (Fig. 1) for a BBG from Khulna those after analysis were confirmed as partial cyt $b$ gene sequence (N-terminal part) of goat mtDNA. Nuclcotide (nt) differences and percentage homologies of the genome fragment sequence (420 bp) of a BBG with the concerned sequences of goats of other countries are given in Table 1.

1 ATTGTAAACA ACGCATTTAT TGACCTCCCA ACCCCATCAA ACATCTCATC ATGATGAAAC TTTGGATCCC TCCTAGGAAT TTGCCTAATC TTACAAATCC TGACAGGCCT ATTCCTAGCA ATACACTATA CATCCGACAC AATAACAGCA TTTTCCTCTG TAACTCACAT TTGTCGAGAT GTAAATTATG GCTGAATCAT CCGATACATA CACGCAAACG GAGCATCAAT ATTCTTTATC TGCCTATTCA TACATATCGG ACGAGGTCTA TATTATGGAT CATATACCTT TCTAGAAACA TGAAACATTG GAGTAATCCT CCTGCTCGCG ACAATGGCCA CAGCATTCAT AGGCTATGTT TTACCATGAG GACAAATATC ATTTTGAGGG GCAACAGTCA TCACTAATCT TCTTTCAGCA

Figure 1. Partial Cytochrome b (CYTB) gene sequence (420 bp, N-terminal part) of itochondrial DNA from a Black Bengal goat (Capra hircus) (Bangladesh-BBG-K-2) of Khulna district.

Phylogenic analysis of the $C y t b$ region of mtDNA has been used extensively to identify and characterize goat species, and investigate the molecular distribution of the goat worldwide (Lestari et al., 2018). mtDNA is an important tool for phylogenetic studies and has been widely used to study genetic differentiation, genetic complexity, evolutionary relationships and origins of many domestic animals 
(Wilson et al., 1985; Carmela et al., 2000) including cattle (Loftus et al., 1994), buffalo (Babar et al., 2011a), sheep (Loehr et al., 2006) and goats (Joshi et al., 2004; Babar et al., 2011b). Sequence data from the BLRI isolates of different goat breeds in this study indicated that the two goat breeds existing during the period of 2010-2011 were closely related to native breeds of Bangladesh and surrounding countries.

Jamunapari (MN066605) and Black Bengal (MN066604) goats are compared with 22 different goat breeds from different countries by drawing phylogenetic (Table 2). The phylogeny tree shows two main clusters which in each cluster there were several subclusters (Fig. 3). Almost all of Jamunapari goats in this study were in the first cluster together with India, Pakistan, China, Japan, Thailand, Malaysia, Japan, France, S. Africa and BBG-K-2 goats, but some of them (S. Korea-a-105, S. Koreab-109, S. Korea-e-139) formed separate subcluster with most of the other Jamunapari (MN066605) and Black Bengal (MN066604) goats. On the other hand, the second cluster was filled by goats from Israel, Italy, USA Switzerland, Slovenia, France, Japan, China and Pakistan. Two sequencing reactions (forward and reverse) for each sample gave $606 \mathrm{bp}$ sequence for a Jamunapari goat (Chowdhury et al. 2011) and $420 \mathrm{bp}$ sequence for a BBG from Khulna those after analysis were confirmed as partial cytb gene sequence ( $\mathrm{N}$-terminal part) of goat mitochondrial DNA. The sequence from BBG had no nucleotide (nt) difference and $100 \%$ homology with the BBG (C. hircus) of India and also the goats from China, Thailand, Japan and South Africa. The sequence had 1-5 nt differences and 99\% homology with the goats from China, Thailand and Japan (other goats), and also with the goats from Malaysia, South Korea, France, Italy, Pakistan, Slovenia, Switzerland and USA. Same similarity (99\%) with only 1 nt difference was found with a Japanese wild goat (Bezoar C. aegagrus), with 2 nt difference was found with a Bangladeshi Jamunapari (MN066605) goat, and with $3 \mathrm{nt}$ difference was found with Israeli goats (Capra hircus and $C$. aegagrus cretica) (Table 2). The sequence had 12-13 nt difference (97\% homology) with Sindh Ibex goats (C. aegagrus blythi) from Pakistan, and with other Indian goat (C. hircus). Sixteen nt difference $(96 \%$ homology) was found with Markhor goats ( $C$. falconeri) of Japan and France. Eighteen to $28 \mathrm{nt}$ difference (96\%-93\% homology) was found (Table 2) with other goats of France $(C$. caucasica, $C$. cylindricornis, $C$. aegagrus, $C$. nubiana and $C$. ibex). This is possible because of geographical distance and distribution. Chowdhury et al., 2011 reported sequencing of Bangladeshi Jamunapari (MN066605) goat has unique at positions 17 and 21 containing $\mathrm{G}$ and G, respectively. For this reason, Jamunapari goat phenotypically has been showed more height, weight and milk production in relation to BBG of Bangladesh. In our present study, BBG of Bangladesh showed unique at positions 17 and 21 containing $\mathrm{T}$ and $\mathrm{T}$, respectively, which may be considered as nucleotide markers of Black Bengal goats. Since these differences BBG gives at least triplet numbers of kid at six months interval of reproduction period. 
Table 2. Nuclcotide (nt) differences and percentage homologies of the sequence (mitochondrial cytb gene partial sequence, $420 \mathrm{bp}$ ) of Black Bengal (Accession No.: MN066604) goat (BBG-K-2) with that of other goats

\begin{tabular}{|c|c|c|c|c|}
\hline Serial no. & $\begin{array}{l}\text { Accession No. } \\
\text { /Identity }\end{array}$ & Country & $\begin{array}{c}\text { No. of nt } \\
\text { differences }\end{array}$ & $\begin{array}{c}\text { Percentage } \\
\text { homology }(\%)\end{array}$ \\
\hline 1. & MN066605 & Bangladesh & 2 & 99 \\
\hline 2. & GU229281 & China & 3 & 99 \\
\hline 3. & EU130773 & China & 2 & 99 \\
\hline 4. & EU130774 & China & 1 & 99 \\
\hline 5. & EU130780 & China & 4 & 99 \\
\hline 6. & EU130775 & China & 0 & 100 \\
\hline 7. & EU130776 & China & 0 & 100 \\
\hline 8. & DQ089480 & China & 5 & 99 \\
\hline 9. & AF034737 & France & 21 & 95 \\
\hline 10. & AF034738 & France & 18 & 96 \\
\hline 11. & AF034735 & France & 28 & 93 \\
\hline 12. & AF034736 & France & 16 & 96 \\
\hline 13. & AF034740 & France & 27 & 94 \\
\hline 14. & GU295658 & France & 1 & 99 \\
\hline 15. & AF034739 & France & 21 & 95 \\
\hline 16. & DQ073048 & India & 0 & 100 \\
\hline 17. & EF056502 & India & 13 & 97 \\
\hline 18. & AF217255 & Israel & 3 & 99 \\
\hline 19. & AF217254 & Israel & 3 & 99 \\
\hline 20. & AF533441 & Italy & 1 & 99 \\
\hline 21. & AB004073 & Japan & 0 & 100 \\
\hline 22. & AB004074 & Japan & 1 & 99 \\
\hline 23. & D84201 & Japan & 5 & 99 \\
\hline 24. & AB044307 & Japan & 0 & 100 \\
\hline 25. & AB044308 & Japan & 1 & 99 \\
\hline 26. & AB044309 & Japan & 16 & 96 \\
\hline 27. & DQ514545 & Malaysia & 1 & 99 \\
\hline 28. & AB110594 & Pakistan & 4 & 99 \\
\hline 29. & AB110595 & Pakistan & 4 & 99 \\
\hline 30. & AB110596 & Pakistan & 3 & 99 \\
\hline
\end{tabular}




\begin{tabular}{|c|c|c|c|c|}
\hline Serial no. & $\begin{array}{l}\text { Accession No. } \\
\text { /Identity }\end{array}$ & Country & $\begin{array}{l}\text { No. of nt } \\
\text { differences }\end{array}$ & $\begin{array}{c}\text { Percentage } \\
\text { homology }(\%)\end{array}$ \\
\hline 31. & AB110597 & Pakistan & 2 & 99 \\
\hline 32. & AB110592 & Pakistan & 12 & 97 \\
\hline 33. & AB110593 & Pakistan & 12 & 97 \\
\hline 34. & DQ514544 & South Africa & 0 & 100 \\
\hline 35. & EU259119 & South Korea & 2 & 99 \\
\hline 36. & EU259120 & South Korea & 1 & 99 \\
\hline 37. & EU259132 & South Korea & 1 & 99 \\
\hline 38. & DQ514547 & Slovenia & 4 & 99 \\
\hline 39. & DQ514548 & Switzerland & 5 & 99 \\
\hline 40. & FJ556564 & Thailand & 0 & 100 \\
\hline 41. & FJ556557 & Thailand & 1 & 99 \\
\hline 42. & X56289 & USA & 5 & 99 \\
\hline 43. & AB004069 & Japan & 1 & 99 \\
\hline
\end{tabular}

Our results were in general agreement with the pattern described in previous studies (Liu et al., 2007; Wang et al., 2008). From NCBI BLAST search of the GenBank, EMBL, DDBJ and PDB databases, no sequence of Jamunapari goat was available. However, unpublished Gene Bank sequences of cytochrome $b$ gene of mitochondrial DNA of Black Bengal goats (BBG) in India (Accession nos. DQ093614 and DQ 073048) had only 3-4 nt differences (Table 2) with high homology (99\%) with the present Jamunapari goat sequence (Chowdhury et al., 2011). Results of sequence analysis of cytochrome $b$ gene of mitochondrial DNA revealed that China-HM13 were closely related to Black Bengal goat (BBG-K-2) of Bangladesh, China-HM18, Japan-AB004073, S. Korea-a-105, S. Korea-b-109, S. Korea-e-139, ThailandGoat01, Japan-AB004069 and also shared $99.5 \%$ to $100 \%$ similarity at the nucleotide level. Significant divergence rates $(0$ to $0.5 \%)$ observed among the goats of above countries. Black Bengal Goat (MN066604) of Bangladesh showed that S. Korea-a105 , S. Korea-b-109, S. Korea-e-139, Japan-AB004069 with $99.5 \%$ to $99.8 \%$ identity were most closely related to BBG-K-2 collected from the Khulna area of Bangladesh. Moreover, it revealed that there was slight divergence $(0.2 \%$ to $0.5 \%)$ of those countries (Fig. 2). Whereas analyses of cytochrome b gene sequences suggested that Jamunapari goats (SG-1) have maximum identity of $99.5 \%$ to $99.8 \%$, and were most closely related to BBG-K-2, China-D-LK18, China-G32, China-HM13, ChinaHM18, India-BBG-DQ073048, Japan-AB004073, Japan-AB004074, PakistanLineage D1, Pakistan-Lineage D2, S. Africa-ChGr642, S. Korea-a-105, S. Korea-b109, S. Korea-e-139, Thailand-Goat01, Japan-AB004069 (Fig. 2). The slight divergence rate $(0.5 \%$ to $1.2 \%)$ was also found (Fig. 3$)$. 
Genetic relationships of Black Bengal (MN066604) Goat (BBG-K-2) and Jamunapari (MN066605) goats (SG-1) of Bangladesh with cytochrome b nucleotide sequences were closely related to China-HM7, China-YP xj46, Pakistan-Lineage C1, Pakistan-Lineage C2, Slovenia- ChSo1, Switzerland-ChTo2992 and shared 98.8\% to $99 \%$ and $98.3 \%$ to $98.6 \%$ similarity, respectively and $1-1.2 \%$ and 1.4 to $1.7 \%$ genetic distance (Fig. 2), respectively. China-HM7 showed $98.8 \%$ to $100 \%$ similarities with China-YP xj46, Pakistan-Lineage C1, Pakistan-Lineage C2, Slovenia- ChSo1, Switzerland-ChTo2992 and slight divergence rate (0\% to $0.2 \%)$.

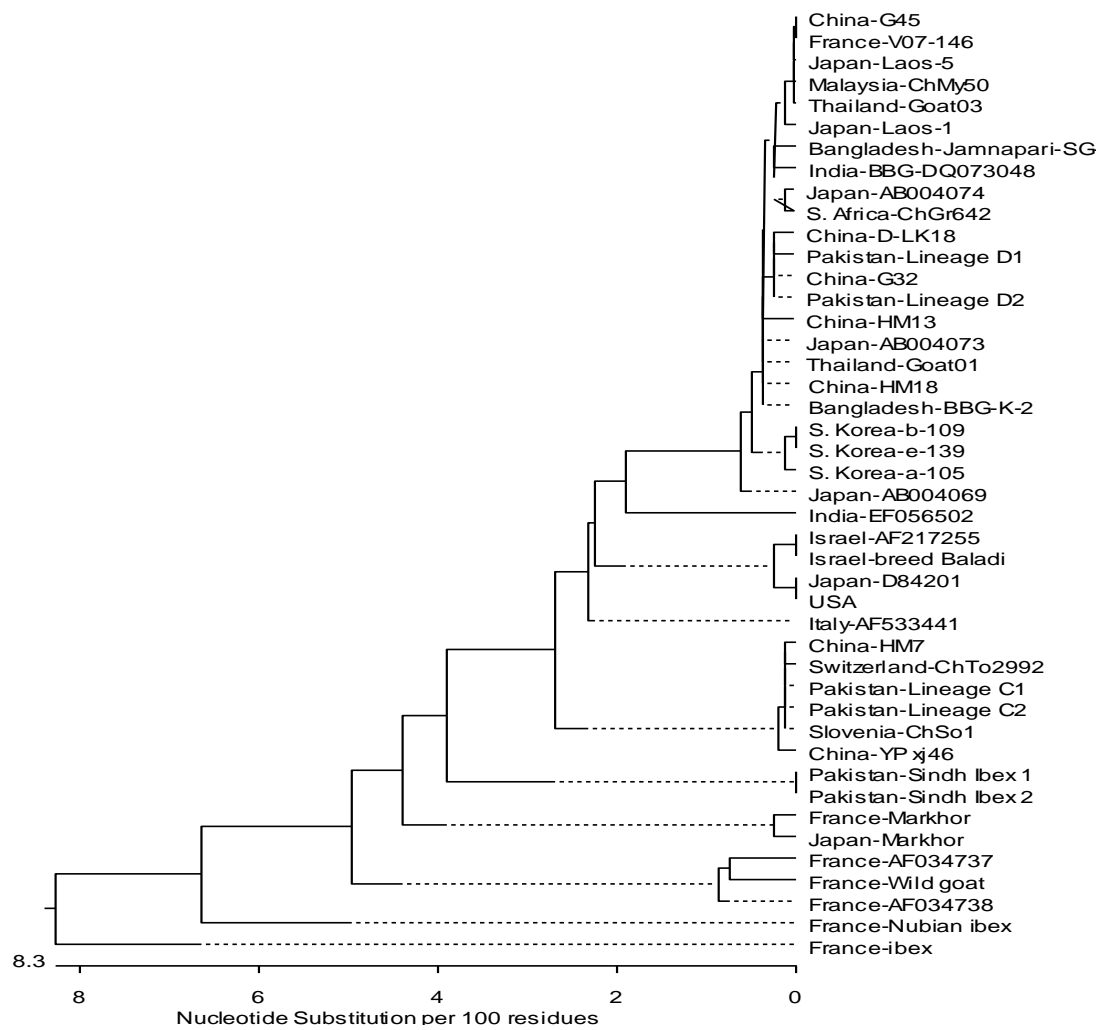

Figure 3. Phylogenetic tree showing the relationships of Black Bengal (BBG-K-2) and Jamunapari goats (SG-1) of Bangladesh with other goats based on partial cytochrome $\mathrm{b}$ gene (420 bp seq) sequence

There was $99 \%$ to $100 \%$ similarity observed for France-V07-146 and Japan-Laos-5 goat in relation to goats of Bangladesh-BBG-K-2, Bangladesh-Jamnapari-SG-1, China-D-LK18, China-G32, China-HM13, China-HM18, India-BBG-DQ073048, Japan-AB004073, Japan-AB004074, Japan-Laos-1, Malaysia-ChMy50, PakistanLineage D1, Pakistan-Lineage D2, S. Africa-ChGr642, S. Korea-a-105, S. Korea-b109, S. Korea-e-139, Thailand-Goat01, Thailand-Goat03, Japan-AB004069 and significant divergence rates ( $0 \%$ to $1 \%$ ) observed. There was high divergence showed 
(7.1\% to $7.6 \%$ and $6.8 \%$ to $7.2 \%$ ) from the sequencing of cytochrome b gene of France-ibex goat and France-Nubian ibex with Black Bengal Goat (BBG-K-2) and Jamnapari goats (SG-1) of Bangladesh (Fig. 2). Sequenced Cytb gene collected from Bangladeshi goat Black Bengal (BBG-K-2) were closely related and shared with the same genetic lineage of India (DQ073048), China HM18, respectively, suggesting a common origin whereas Bangladeshi Jamnapari goat (SG-1) showed 99.5\% similarity with India (DQ073048) and BBG-K-2 (MN066604) of Bangladesh (Fig. 3).

\section{CONCLUSIONS}

Black Bengal and Jamunapari goats of Bangladesh have a close genetic relationship to several local goats in Southeast Asia. We speculated that gene flow among goat populations facilitated by the traditional seasonal pastoralism and annual longdistance migrations in history as well as trade would account for the pattern discerned in regional goat pools.

\section{ACKNOWLEDGEMENTS}

We acknowledge Bangladesh Livestock Research Institute, Savar, Dhaka for funding of this research work. The cooperation for the deposition of DNA sequence into GenBank provided by Dr. Jayedul Hassan of the Department of Microbiology and Hygiene, Bangladesh Agricultural University, Mymensingh is accordingly acknowledged.

\section{Conflicts of interest}

Authors have no financial and other conflicts of interest to declare.

\section{REFERENCES}

Avise, J.C. (1994). Molecular markers, natural history and evolution. Chapman and Hall, New York NY

Babar, M.E., Hussain, T., Imran, M., Nagarajan, M., and Kumar, S. (2011a). Mitochondrial DNA diversity patterns in Pakistani buffalo. Animal Genetics, 43(3):315-7

Babar, M. E., Hussain, T., Sadia, H., Shaheen, M., Nadeem, A., Ali A., Wajid, A., and Shah, S.A. (2011b). Molecular characterization, evaluation and conservation of indigenous goat breeds of Pakistan. Proceedings of RBI 8th Global Conference on the Conservation of Animal Genetic Resources Tekirdag, Turkey, 4-8 October,2011: 43-50

Carmela, G., Reyes, A., Pesole, G., and Saccone, C. (2000). Lineage-Specific Evolutionary Rate in Mammalian mtDNA. Molecular Biological Evolution, 17 (7):1022-1031

Castresana, J. (2001). Cytochrome b phylogeny and taxonomy of great Apes and Mammals. Molecular Biological Evolution, 18(4): 465-471

Chowdhury, S.M.Z.H., Kamaruddin, K.M., Taimur, M.J.F.A., Ershaduzzaman, M., Rahman, M.M., Al-Faruque, M.H., Alam, M.S., Asaduzzaman, M., Rahman, M.L., and Badhy, S.C. (2011). Polymerase Chain Reaction and Molecular Sequencing for Characterization of Goat Genome. Bangladesh Veterinary Journal, 45(1-4): 11-19 
Draft, S.F.Y.P. (2010). The draft sixth five year plan. 2011-2015. Planning commission, Government of Bangladesh. Paper presented at the Workshop held on $6^{\text {th }}$ January, 2010 in DLS conference room, Dhaka

DLS (2018). Livestock statistics. Department of livestock services. Memeogram. Dhaka, Bangladesh

Dorji, T., Kameda, M., Lin, B.Z., Takahashi, A., Oyama, K., Sasazaki, S., Yamamoto, Y., Kawamoto, Y., and Mannen, H. (2010). Mitochondrial DNA variation and genetic construction of indigenous cattle population in Bhutan. The Journal of Animal Genetics, 38:77-81

Felsenstein, J. (1985). Confidence limits on phylogenies: An approach using the bootstrap. Evolution, 39: 783-791

Fernández, H., Hugues, S., Vigne, J.D., Helmer, D., Hodgins, G., Miquel, C., Hanni, C., Luikart, G., and Taberlet, P. (2006). Divergent mtDNA lineages of goats in an Early Neolithic site, far from the initial domestication areas. Proceedings of the National Academy of Science, USA, 103:15375-15379

Hall, T.A. (1999). Bio edit: a user-friendly biological sequence alignment editor and analysis program for Windows 95/98/NT. Nucleic Acids Symposium Series, 41:95-98

Islam, A., Singha, A., and Islam, M.A. (2011). Peste des petits ruminants of goats, outbreak and economic losses. Pakistan Journal of Scientific and Industrial Research, 54:76-82

Jain, S., Brahmbhait, M.N., Rank, D.N., Joshi, C.G., and Solank, J.V. (2007). Use of Cytochrome $b$ gene variability in detecting meat species by multiplex PCR assay. Indian Journal Agricultural Sciences, 77(9): 880-881

Joshi, M.B., Rout, P.K., Mandal, A.K., Tyler-Smith, C., and Singh, L. (2004). Phylogeography and origin of Indian domestic goats. Molecular Biological Evolution, 21(3): 454-462

Kumar, S., Tamura, K., Jakobsen, I.B., and Nei, M. (2004): Molecular Evolutionary Genetics Analysis Software. Arizona State University Press, Tempe, USA

Larkin, M.A., Blackshields, G., Brown, N.P., Chenna, R, McGettigan, P.A., McWilliam, H., Valentin, F., Wallace, I.M., Wilm, A., Lopez, R., Thompson, J.D., Gibson, T.J., and Higgins, D.G. (2007). Clustal W and Clustal X version 2.0. Bioinformatics, 23(21): 2947-2948

Lestari, D.A., Purbowati, E., Sutopo, S., and Kurnianto, E. (2018). Amino acid sequence based on Cytochrome $b$ gene in Kejobong goat and its genetic relationships among several local goats in Asia. Veterinary World, 11(8): 1196-1202

Liu, R.Y., Lei, C.Z., Liu, S.H., and Yang, G.S. (2007). Genetic diversity and origin of Chinese domestic goats revealed by complete mtDNA D-loop sequence variation. Asian Australian Journal of Animal Science, 20: 178-183

Loehr, J., Worley, K., Grapputo, A., Carey, J., Veitch, A., and Coltman, D.W. (2006). Evidence for cryptic glacial refugia from North American mountain sheep mitochondrial DNA. Journal of Evolution Biological, 19(2): 419-430

Loftus R.T., MacHugh, D.E., Bradley, D.G., Sharp, P.M., and Cunningham, P. (1994). Evidence for two independent domestications of cattle. Proceedings of the National Academy of Science, USA, 1994, 91(7):2757-2761 
Manceau, V., Crampe, J.P., Boursot, P., and Taberlet, P. (1999). Identification of significant evolutionary unit in the Spanish wild goat, Capra pyrenaica (Mammalia artiodactyla). Animal Conservation, 2(1): 33-39

Mannen, H., Nagata, Y., and Soichi, T.S. (2001). Mitochondrial DNA reveal that domestic goat (Capra hircus) are genetically affected by two subspecies of bezoar (Capra aegagurus). Biochemical Genetics, 39: 5/6

Mohammadi, S.B., Afshari, K.P., and Seyedabadi, H.R. (2018). Mitochondrial diversity and phylogenetic structure of native Iranian goat population compared with 4 improtant livestock species. International Journal of Veterinary Sciences and Animal Husbandry, 3(2): 20-25

Saitou, N., and Nei, M. (1987). The neighbor-joining method: a new method for reconstructing phylogenetic trees. Molecular Biological Evolution, 4(4): 406-425

Tamura, K., Stecher, G., Peterson, D., Filipski, A., and Kumar, S. (2013). MEGA6: Molecular evolutionary genetics analysis version 6.0. Molecular Biological Evolution, 30(12): 2725-2729

Tamura, K., and Dudley, J. (2007). MEGA4: Molecular Evolutionary Genetics Analysis (MEGA) software version 4.0. Molecular Biological Evolution, 24 (8): 1596-9

Tamura, K., and Nei, M. (1993). Estimation of the number of nucleotide substitutions in the control region of mitochondrial DNA in humans and chimpanzees. Molecular Biological Evolution, 10:512-526

Thompson, J.D., Higgins, D.G., and Gibson, T.J. (1994). CLUSTAL W: Improving the sensitivity of progressive multiple sequence alignment through sequence weighting, position-specific gap penalties and weight matrix choice. Nucleic Acids Research, 22(22): 4673-4680

Wang, J., Chen, Y.L., Wang, X.L., and Yang, Z.X. (2008). The genetic diversity of seven indigenous Chinese goat breeds. Small Ruminant Research, 74: 231-237

Wilson, A.C., Cann, R.L., Carr, S.M., George, M., Gyllensten, U.B., Helm-Bychowski, K.M., Higuchi, R.J., Palumbi, S.R., Prager, E.M., Sage, R.D., and Stoneking, M. (1985). Mitochondrial DNA and two perspectives on evolutionary genetics. Biology Journal of Linnean Society, 26(4): 375-400

Zeder, M.A. (2008). Animal domestication in the Zagros: An update and directions for future research" in Archaeozoology of the Near East, VIII: Proceedings of the Eighth International Symposium on the Archaeozoology of Southwestern Asia and Adjacent Area. Edited by Emanuelle Vila, Lionel Goucherin, Alice Choyke, and Hilke Buitenhuis : 243-78 